\title{
Family Communication Patterns of Abuser and Victim in Sexual Abuse Case Resolutions towards Children in Medan City Resort Police
}

\author{
Haslinda $^{1}$, Lahmuddin Lubis ${ }^{2}$, Syukur Kholil ${ }^{2}$ \\ ${ }^{1}$ Ph.D Student in Islamic University of North Sumatera (UINSU), Medan, Indonesia \\ ${ }^{2}$ Lecturer in Islamic University of North Sumatera (UINSU), Medan, Indonesia
}

\begin{abstract}
This study aims to analyze the family communication patterns of abuser and victim in sexual abuse case resolutions towards children, the application of the principles of Islamic communication in resolving sexual abuse cases towards children and to know the obstacles in solving sexual abuse cases for underage children in the law area of Medan City Resort Police. The research method used in this study is a descriptive qualitative approach. This method describes the current state of the subject or object of study based on facts that appear or as they are. The results of the study shows that the family communication patterns of abuser and victim in sexual abuse case resolutions towards children in Medan City Resort Police are the Equality Pattern, Balance Split Pattern, Unbalanced Split Pattern and Monopoly Patterns.
\end{abstract}

Keywords : Family communication patterns; sexual abuse case resolutions; children in Medan City Resort Police.

\section{Introduction}

Children are the future not only for themselves and their families, but also for their communities, nations and countries. Children are the future of humanity, without children, there is no future for anyone. Not paying attention to the quality of life of a children is the same as not paying attention to family survival. ${ }^{1}$

Children are also the mandate and gift of God Almighty, in which the dignity of a whole person is attached to them. Children need to get the widest opportunity to grow up and develop optimally both physically, mentally and socially so that they can become the next generation of aspirations for the nation's struggle and are expected to guarantee the continuity of the existence of the nation and state.

Children as individuals who live in families and communities cannot be separated from social problems and also become victims of an unpleasant act such as sexual abuse. Children experience sexual abuse both in the household, on the streets, at school, and among their peers. ${ }^{2}$

Sexual abuse is part of a crime against decency. Sexual abuse not only occur in adults but also occur in underage children. Both directly and indirectly the children who are victims of sexual abuse experience various physical and non-physical disturbances caused by the incident. ${ }^{3}$

In some sexual abuse cases of children was identified that sexual abuser could be children, the people closest to the victim or the family of the victim, even in some instances done because of the liking between the victims and sexual abuser. So in such a condition, it is often done to resolve cases of sexual abuse through reasoning (peace) mediation and those who have a central role in the occurrence of peace are the Police.

Penal mediation is an alternative form of dispute resolution outside the court that is possible to do (commonly known as ADR or "Alternative Dispute Resolution", some call it

\footnotetext{
${ }^{1}$ ECPAT, Memerangi Pariwisata Sex Anak, (SUMUT: Koalisi Nasional Penghapusan ESKA, 2008), p. 3.

${ }^{2}$ Arif, Gosita, Masalah Korban Kejahatan (Kumpulan Karangan), (Jakarta: Akademika Pressindo, 1993 ), p.33.

${ }^{3}$ Leden, Marpaung, Kejahatan Terhadap Kesusilaan dan Masalah Preverensinya, (Jakarta Sinar Grafika, 2004). p.41.
} 
"Appropriate Dispute Resolution"). The background of the ideas of "reforming reason" include the idea of victim protection, the idea of harmonization, the idea of restorative justice, the idea of overcoming rigidity / formalities in the prevailing system, the idea of avoiding the negative effects of the criminal justice system and the current criminal system, in particular in looking for other alternatives from imprisonment (alternative to imprisonment / alternative to custody) and so on.

The number of sexual abuse cases for underage children handled by Medan City Resort Police has made researchers interested in studying them, where sexual abuse cases usually involve families in their resolution. Many families who want this problem are resolved in a family manner without having to go through legal processes such as peace and marriage. There are also families of victims of sexual abuse who only want compensation for the acts of sexual abusers against their family members.

\section{Review of Literatures}

\subsection{Family Communication}

The word communication comes from the word communicare which in Latin means to participate, or comes from the word commons which means the same $=$ common. ${ }^{4}$ The term communication in an Indonesian dictionary is the sending and receiving of messages or news between two or more people so that the message in question can be understood. ${ }^{5}$ According to Stanly J. Baran in his book "Introduction to Mass Communication: media literacy and culture", in its simplest communication from a transmission from a source to a receiver. The purpose of the definition above is, a simple understanding of communication is the process of transferring messages from source to recipient. ${ }^{6}$

According to Suharsimi Arikunto in his book "Organization and Administration", Communication is a process where the message is conveyed by the messenger to the recipient. The message can be in the form of feelings or the results of one's own thoughts, or just a continuation of the feelings or thoughts of others, with the intention of changing the knowledge, skills and / or attitudes of the recipient of the message. ${ }^{7}$

While the family according to Kusdwiratri Setiono is a group of people who have blood relations or marriage. The people who belong to the family are the mother, father and children. ${ }^{8}$ According to Soelaeman quoted by Moh. Shohib in his book "Pola Asuh Orang Tua ", a family is a group of people who live together in a place to live together and each member feels that there is an inner connection so that there is mutual influence, mutual attention and mutual surrender. ${ }^{9}$

To harmonize the duties of family members, communication between one family member and another is needed. Communication in the family has a very important role because communication affects the harmony of a family. So a harmonious family must have smooth communication. In addition, communication in the family can be said to succeed if the

\footnotetext{
4 Toto Tasmara, Komunikasi Dakwah, (Jakarta: Gaya Pratama, 1997), p. 3.

${ }^{5}$ Depdikbud RI, Kamus Besar Bahasa Indonesia, (Jakarta: Balai Pustaka, 2005), p. 585.

${ }^{6}$ Stanly J. Baran, Introduction Mass Communication: Media Literacy and Culture, (New York: McGraw-Hill, 2009), p. 4.

${ }^{7}$ Suharsimi Arikunto, Organisasi Dan Administrasi, (Jakarta: Grafindo Persada, 1993), p. 207.

${ }^{8}$ Kusdwiratri Setiono, Psikologi Keluarga, (Bandung: P.T. Alumni, 2011), p. 24.

${ }^{9}$ Moh. Shochib, Pola Asuh Orang Tua, (Jakarta: PT Rineka Cipta, 1998), p. 17.
} 
information, education or message delivered can be received well by family members who receive the message and according to the goals planned by family members who convey the message, so that there will be good reciprocity between family members without any misunderstanding in communication. Thus, a harmonious family will be realized.

\subsection{Family Communication Pattern}

Many theories about family communication state that family members carry out the same pattern of interaction continuously. This pattern can be negative or positive, depending on the point of view and the consequences that family members receive. The family makes an agreement about what is permissible and which cannot be communicated and how the contents of the communication are interpreted. Families also create rules when they can communicate, such as not being able to talk when people are trying to sleep, and so on. All the rules and values contained therein are communicated in the same way continuously so as to form a pattern of family communication.

The communication pattern that occurs in the family can be expressed directly or only inferred from the behavior and treatment that occurs in the family. The family needs to develop awareness of the patterns of interaction that occur within the family, whether the pattern is truly desirable and acceptable to all family members, whether the pattern helps in maintaining the health and function of the family itself, or even damages the integrity of the family. Awareness of the pattern can be distinguished between healthy and happy families with troubled families.

More complex communication patterns develop when the child starts to grow and puts himself in the role of others. According to Hoselitz, by placing the person in the role of others, the child also learns to conform to the expectations of others. ${ }^{10}$

With the expansion of the social sphere and the existence of contact with peers and adults outside the home, this initial foundation, which is placed at home, may change and be modified, but will never disappear altogether. On the contrary, this foundation affects patterns of attitudes and behavior in the future.

$\mathrm{CH}$ Cooley argues that families as a primary group, each member has a special meaning that cannot be replaced by other members without disturbing emotions and relationships within the group. ${ }^{11}$ Members of a family, husband and wife and children have their respective status and roles. Respectively, so that their interactions show a clear and fixed pattern. The status of these family members is so important that if one family member leaves a family bond or relationship, the other members will feel something unpleasant in his heart, besides that the pattern of relations in the family will change. Each family member is a distinctive personality and is needed equally by other members.

\subsection{Family Communication Obstacles}

It is not easy to communicate effectively. Even some communication experts state that it is impossible for someone to actually communicate effectively. There are many obstacles that can cause communication to fail. ${ }^{12}$ Communication patterns have different effects on interpersonal relationships. It is not true that people think that the more often people do interpersonal communication with others, the better their relationship. The problem is not how

\footnotetext{
${ }^{10}$ Alo Liliweri, Memahami Peran Komunikasi Massa Dalam Masyarakat, (Bandung: Citra Aditya, 1991), p. 45.

${ }^{11}$ Daryanto. Pengantar Sosiologi. (Bandung: IKIP, 2004), p. 64.

${ }^{12}$ Effendy, Onong, Uchjana, Dimensi-dimensi Komunikasi, (Bandung: Alumni, 1992), h.45.
} 
many times the communication is done. But how is the communication carried out. We will see that in a family communication is very much needed, lack of communication with family members (parents with children) and how we will communicate with our family members, all of which will determine a harmonious relationship between one family member and another family member.

In communicating, cannot be separated from various obstacles, this is due to, among other things, the interference both from outside and from the person who is communicating. Disturbances originating from outside include voices of people fighting, loud car sounds, views of someone suspicious and so on. While the interference originating from people who are communicating, among others: anger, sadness and so on that causes concentration in communication is disrupted.

Communication barriers that must be a concern for communicators if they want successful communication in the sense that here are parents with children are 1) disturbances: mechanics that is interference caused by communication channels or noise that is physical, semantics that is related to communication messages whose understanding is broken through language use; 2) Interest that is someone will be selective in responding or living a message; 3) Hidden Motivation will encourage someone to do something that is right with their desires, needs and disadvantages; 4) Prejudice is one of the obstacles or a heavy obstacle for a communication activity because people who have prejudice have not been suspicious and oppose communicators who want to communicate. ${ }^{13}$

\subsection{Group Communication}

Groups are some of people who have a common goal that interacts with each other to achieve common goals, get to know each other, and view them as part of the group. This group, for example, is a family, discussion group, problem solving group, or a committee that is meeting to make a decision. In group communication, it also involves interpersonal communication. Therefore most interpersonal communication theories also apply to group communication.

Group communication is communication that takes place between several people in a "small" group such as in meetings, meetings, conferences and so on. Michael Burgoon defines group communication as face-to-face interaction between three or more people, with known goals, such as sharing information, protecting oneself, solving problems, where members can remember the personal characteristics of other members appropriately. The two definitions of communication of the groups above have in common, namely the presence of face-to-face communication, communication participants of more than two people, and having a specific work plan arrangement to achieve group goals.

Group communication occurs when three people or more face to face, usually under the direction of a leader to achieve common goals or targets and influence each other. More deeply the three scientists outlined the characteristics of group communication as follows:

1. Groups communicate through face to face

2. Groups have few participants

3. Group works under the direction of someone's leader

4. Groups share common goals or objectives

5. Group members have influence over each other

${ }^{13}$ Ibid, p. 49. 


\subsection{Criminal Acts of Sexual Abuse}

Sexual abuse is an attempt to vent sexual appetite by a man towards a woman in a manner according to morals and or applicable law violates. Revocation on the one hand is an act or action of a man who vents his sexual appetite for a woman where the act is immoral and prohibited according to applicable law. ${ }^{14}$

Sexual abuse is a tendency to engage in sexual activity with people who are helpless like children, both men and women, in violence or without violence. The meaning of sexual abuse or obscenity in Indonesian Dictionary is interpreted as follows: sexual abuse is the basic word of obscene, which is lewdness and vile which is not in accordance with manners (indecent), not moral, fulfilling: committing adultery, committing immoral crimes, cheating: obscenity, raping, women's defamation, film.

From the description above, that sexual abuse is a man who made an attempt to force and threat and sexual intercourse with a woman who was not his wife and from intercourse resulted in the discharge of a man's semen.

Assumptions that do not agree in terms of defining sexual abuse do not take into account whether or not the element regarding the discharge of semen as stated by Lamintang rape is the act of someone who violently or threatens to force a woman to commit sexual intercourse with her. ${ }^{15}$

Based on this opinion, this proves that the existence of violence and the threat of violence by being killed, injured, or deprived of other human rights are parts to facilitate the conduct of intercourse.

\section{Discussion}

Basically everyone wants recognition, attention, praise, and love from their environment, especially from their parents or family, because naturally parents and families have very strong emotional bonds. From the observation conducted by researchers on the pattern of family communication in solving obscene cases against minors, researchers saw the role of communication carried out by parties such as the families of victims of sexual abuse with family members of abusers in resolving obscene cases of minors. Communication patterns carried out by the parties varied in the form of attention, motivation, discussion, appreciation and understanding carried out by the parties so that the communication carried out went well with input from psychology, religious leaders and investigators.

From the observation conducted by researchers on the family communication patterns in solving sexual abuse cases for underage children, researchers found four communication patterns, namely:

\subsection{Equality Pattern}

In this pattern, each individual shares the same rights in communication opportunities. The role of each person is carried out evenly. Communication runs honestly, openly, directly, and free from the division of power. Everyone has the same rights in the decision making process. Families get the highest power if there is equality. In family communication to families who have cases of underage children, each person is considered equal and of equal ability, free to express ideas, opinions, and beliefs in which the victim's family and the family of the

\footnotetext{
${ }^{14}$ Topo, Santoso, Seksualitas Dan Hukum Pidana, (Jakarta : IND-HILL-CO, 1997), p. 67.

${ }^{15}$ Lamintang, P.A.F. Dasar-Dasar Hukum Pidana Indonesia, (Bandung: Citra Aditya Bakti, 1997 ), p. 193.
} 
offender have the right to convey their aspirations or ideas in solving problems between the two families that is.

From the observation that researchers conducted on family communication patterns in solving sexual abuse cases for underage children, researchers found that many parents did not know the patterns and forms of their children's behavior. This is as the result of an interview with JN parents who was the victim of sexual abuse "Ouch I am very disappointed because I did not think my child was so and I trusted my child too much all this time. Well this is the result, I was sad and very embarrassed by my siblings, neighbors and also, "informant $\mathrm{Z}$ told researchers.

To avoid embarrassment due to the actions of this child, the parents of the sexual abuse took the initiative to communicate with the abuser. And at the beginning of the communication carried out by parents the abuser did not respond to the communication conveyed by parents of victims of sexual abuse. This is as the result of an interview with FT parents of the victim of sexual abuse who explained "Already coming to the parents of the sexual abuser home and informing them that the abuser impregnated the victims of his girlfriend, but the abuser parents ignored my arrival and talk to him, because he was the parent of the abuser. I was home with my brother, so I returned home and the next day I immediately reported the abuser actions towards the victim to the authorities, when the abuser were picked up by police officers, then his mother came to me asking for peace ", informant $\mathrm{Z}$ told researchers.

With the action of the family of the victim of sexual abuse reporting the sexual abuse incident to the Police then the communication process will occur and the sexual abuse does not reach the court. This is as the result of an interview with the parents of the SW victim who explained that "at first as the victim came to the family of the abuser and the family of the abuser (the parent of the abuser) promised to hold a discussion first and then give an answer at the next meeting, but after waiting a few days and the abuser's family did not give news so I was as the victim immediately reported the incident experienced by the victim to the Police Office so that the legal process was carried out but after I reported the abuser the authorities were followed up by the abuser, begging my parents to come to my house so that the case that is happening can be resolved in a family manner and the abuser is willing to marry the victim "," said the KS informant to the researcher.

Communication that takes place runs honestly, openly, directly, and free from the separation of powers that occurs in other in-person relationships. In this pattern there are no leaders and followers, opinionates and opinion seekers, everyone plays the same role. Communication deepens the recognition of one another, through the intensity, depth and frequency of each other's self-recognition, as well as nonverbal behaviors such as balanced amount of touch and eye contact. Every person has the same rights in decision making, both as simple as the film to be watched and important such as which school children will enter, buying a house, and so on. Conflicts that occur are not considered a threat. Problems are observed and analyzed. Dissent is not seen as one less than the other but as an unavoidable clash of ideas or differences in values and perceptions that are part of a long-term relationship.

\subsection{Balance Split Pattern}

Equality of relations is maintained, but in this pattern each person has a different area of power than the others. Everyone is seen as an expert in a different field. In this pattern each person holds control or power in their respective fields. Everyone is considered an expert in a different area. For example, in an ordinary family, a husband is trusted to work / earn a living 
for his family and wife taking care of children and cooking. In this pattern, it is possible that all members have the same knowledge about religion, health, art, and one party is not considered more than the other. Conflicts that occur are not considered a threat because each person has their own territory. So that before the conflict occurred, it was determined who won or lost. For example, if a conflict occurs in terms of business, the husband wins, and if the conflict occurs in matters of child affairs, the wife wins. But no party has been harmed by the conflict because each has its own territory.

In terms of this communication pattern the position of religious leaders, investigators and psychologists is placed in a neutral position. As the investigator from the Pancurbatu Mesrahati police said, "Investigators in processing cases of children as victims of sexual abuse continue to prioritize the best interests of children," said informant Mesrahati to the researchers.

According to the informant Suryani Hardjo, S.Psi, M.A, as a psychologist, the resolutions by involving the family of the victim and the family of the perpetrator who concludes with peace and not proceeding the legal process can change the behavior of the victim or the abuser himself (effect). "Because feeling protected, respected, defended by the family but does not change the sexual trauma by the victim because it is needed by experts to eliminate the trauma. For the perpetrators will feel satisfied and will not change the behavior of sexual deviation if he does not feel wrong in terms of ethics, law or feel guilty that will lead to freedom (he needs people to overcome sexual deviations ", said informant Suryani Hardjo, S.Psi, MA to researchers.

Informant Suryani Hardjo, S.Psi, M.A suggested for victims that the community or family should not blame, it would be better if the victim was embraced again, taught religion when to take treatment for consultation and treatment in connection with unwanted sexual treatment. For abuser, families need to be involved to deal with deviant sexual behavior and need to involve the ulema, competent community leaders and to cause deterrent effects, the abuser need to be punished and this punishment can also be given to the family.

Revocation of fellow minors will certainly have an impact on the psychological and other developments of the child, especially for victims. The psychological impact on children will give birth to prolonged trauma which can then give birth to unhealthy attitudes, such as inferiority, excessive fear, impaired mental development, and ultimately result in mental retardation. This situation could possibly be a bad memory for the children of sexual abuse's victim.

\subsection{Unbalanced Split Pattern}

In this pattern, one person dominates, one person is considered more expert than the other. One person is the one who holds control, this person usually has a higher intellectual intelligence, is wiser, or has a higher income. Other family members compensate by submitting to the person, allowing the dominating person to win their own arguments and decision making.

Based on the results of the research in the field the researchers found each family of victims of sexual abuse and the family of sexual abuser carrying several family members who were considered able to consult with other family members, both with the families of sexual abuser and family of victims of sexual abuse.

As stated by informant HA to researchers that he brought several members of his family such as uncle, aunt and grandparents from sexual abuse victims to be able to conduct deliberations with the families of the perpetrators in order to get the best solution for the future of their family members involved in sexual abuse. 
The family communication patterns in solving sexual abuse cases for underage children initially originated from the families of victims of sexual abuse with the family of the abuser. Communication that is usually carried out at first does not give birth to an agreement to resolve the case of sexual abuse. Furthermore the family of victims of sexual abuse took action in the form of reporting cases of sexual abuse to the authorities. With the report made by victims of sexual abuse to the police, then the current communication pattern is the arrival of families of abuser to carry out further communication so that the sexual abuse case can be resolved peacefully and not resolved through the court.

All informants' answers explained that the family communication patterns in solving sexual abuse cases for underage children was done to avoid parents of abuse from shame or disgrace and to avoid pregnant children from having husbands. Meanwhile, the abuser of communication abuses that went on as a manifestation of avoiding sexual abuser who eventually went to prison. This is as the result of an interview with parents of AA abusers who explained that "the thing that causes parents of abusers who do not wish to carry out legal proceedings as sexual abuser until completion is the reason for fear of children being imprisoned", said the WI informant to researchers.

The result of the family communication patterns in solving sexual abuse cases for underage children is a marriage or in the form of compensation. So that there are two forms of results achieved in communication carried out, that is peace by marrying them or made peace in the form of compensation from the families of sexual abuser to victims of sexual abuse.

Another thing found in the family communication patterns in solving sexual abuse cases for underage children is the involvement of the family in resolving the sexual abuse case. The family here functions to be asked for their opinion as well as to represent one party in communicating with the other party. The existence of this family is very important to get the final results of the communication process to resolve sexual abuse cases. The results of the Interview with Psychology explain that the family is very important because it involves the good name of the family and other considerations in social life with the community.

The influence or role of the family both from the victim and the abuser, in responding to the abuse cases that occur so that the realization of peace plays an important role for parents because it is the parents of children who have more roles (adherence to parents ethically and religiously).

Selective attention that must be considered among us is we pay attention to certain things according to our beliefs, attitudes, values, habits and interests. We tend to strengthen existing beliefs, attitudes, values and interests in directing our attention, both as communicators.

Parents generally have an interest in their children by paying attention in the form of advice to their children regarding activities carried out by teenagers in general so that the messages conveyed through communication can work well. It's just that the attention given is less useful for the child so that the child commits a disgraceful act for the reason of dating

Personal understanding that is built all the time, can encourage us to understand and be willing to be understood we share secrets, fears and personal experiences with someone who is trusted, but not for everyone else. This is what Buber said with us being fully human in front of other people. Personal understanding is a process that grows and develops as long as we communicate interpersonally.

Parents in general often give understanding to adolescents about activities carried out by adolescents both in the family and in the environment so that the existing problems can be 
overcome by parents in order to create an open mindedness in fostering effective interpersonal communication.

\subsection{Monopoly Pattern}

One person is seen as the holder of power. One person is more giving orders than communicating. He has the full right to make decisions so that rarely or never ask or ask for opinions from others. The power of attorney orders the others what is allowed and not done. Then the other family members ask permission, ask for opinions, and make decisions based on the decision of the person.

The result of the family communication patterns in solving sexual abuse cases for underage children is a marriage or in the form of compensation. So that there are two forms of results achieved in communication carried out, that is peace by marrying them or made peace in the form of compensation from the families of sexual abuser to victims of sexual abuse.

Another thing found in the family communication patterns in solving sexual abuse cases for underage children is the involvement of the family in resolving the sexual abuse case. The family here functions to be asked for their opinion as well as to represent one party in communicating with the other party. The existence of this family is very important to get the final results of the communication process to resolve sexual abuse cases. The results of the Interview with Psychology explain that the family is very important because it involves the good name of the family and other considerations in social life with the community.

The influence or role of the family both from the victim and the abuser, in responding to the abuse cases that occur so that the realization of peace plays an important role for parents because it is the parents of children who have more roles (adherence to parents ethically and religiously).

Based on the description above, it can be understood that in the family communication patterns in solving sexual abuse cases for underage children, it requires the attention of all parties to jointly resolve cases of abuse. Attention is a mental process when a stimulus or set of stimuli becomes prominent in consciousness when another stimulus is weakened

Parents generally have an interest in their children by paying attention in the form of advice to their children regarding activities carried out by teenagers in general so that the messages conveyed through communication can work well. It's just that the attention given is less useful for the child so that the child commits a disgraceful act for the reason of dating

Personal understanding that is built all the time, can encourage us to understand and be willing to be understood we share secrets, fears and personal experiences with someone who is trusted, but not for everyone else. This is what Buber said with us being fully human in front of other people. Personal understanding is a process that grows and develops as long as we communicate interpersonally.

This differentiation of communication patterns illustrates the division of roles and positions of each individual in a family. The pattern of family communication plays a role in receiving messages and feedback that occurs between family members. For example in the monopoly communication pattern, only one person has the right to make decisions in the family. This causes other family members not to have the right to voice opinions or play a role in decision making, which results in family communication tend to be one-way communication only. Likewise in the planting and development of values, the values instilled by holders of power are absolutely followed by other family members because communication that takes place is only an instruction or an order. 
The family has a very big role in teaching, guiding, determining behavior, and forming the child's perspective on the values that apply in society. The family is like giving the values that are needed by the child through an appropriate communication pattern so that communication goes well, harmonious relationships are created, and the messages and values to be conveyed can be accepted and practiced properly.

\section{Conclusion}

The family communication patterns of perpetrator and victim in sexual abuse case resolutions towards children in Medan City Resort Police:

1. Equality Pattern: family communication patterns in solving sexual abuse cases for underage children can be by marrying off the victim with the sexual abuser or by giving compensation for the family of the abuser to the family of the victim where each family can equally accept the agreed decision.

2. Balance Split Pattern: because of the family of the sexual abuser does not accept the summons faced by the family of the victim of sexual abuse, so that the family of victim of sexual abuse involves the law enforcement apparatus in this case the investigator, at that time the investigator who acts as a mediator in the case of sexual abuse by bringing together the two families, so that the families of the sexual abuser and the families of the victims can understand and accept the results of their meetings.

3. Unbalanced Split Pattern: in making peace against sexual abuse cases for underage children as victims, unbalanced communication is found when the family finds out what the victim experienced, then the victim's family will try to meet the family of the abuser receive a victim's request that the offender be held accountable for his / her actions against the victim, usually the victim's family will come to the abuser's family several times and if no agreement is reached, the victim's family will report to the authorities for the actions taken according to the applicable law.

4. Monopoly pattern: this communication is seen in resolving sexual abuse cases for underage children as victims, if each party puts forward someone who is considered to have an important role in the family such as uncle, close friend who has wide association. This communication pattern is rarely successful because each family is fixated on what the family said was very instrumental earlier, while the families of the problematic parties (the abuser and victims) actually did not accept these methods.

\section{References}

Al-Qur'an

Atmasasmita, Romli, Kapita Selekta Hukum Pidana dan Kriminologi, Bandung: Mandar Maju, 1995.

Arifin, Anwar. Ilmu Komunikasi Sebuah Pengantar Ringkas. Jakarta: Raja Grafindo Persada, 2002.

Bungin, Burhan. Metode Penelitian Kuantitatif: Komunikasi, Ekonomi, dan Kebijakan Publik serta Ilmu-ilmu Sosial Lainnya. Jakarta: Kencana., 2006

Cangara, Hafied. Pengantar Ilmu Komunikasi. Cetakan IV, Jakarta: Raja Grafindo Persada, 2004. 
Chazawi, Adami, Tindak Pidana Mengenai Kesopanan, Jakarta : PT. Raja Grafindo Persada, 2005.

Daryanto. Pengantar Sosiologi. Bandung: IKIP. 2004.

De Vito, Joseph, A, The Interpersonal Communication Book, Professional Book, Jakarta, 1989.

ECPAT, Memerangi Pariwisata Sex Anak, SUMUT: Koalisi Nasional Penghapusan ESKA, 2008.

Effendy, Onong, Uchjana, Dimensi-dimensi Komunikasi, Bandung: Alumni, 1992.

Gosita, Arif, Masalah Korban Kejahatan (Kumpulan Karangan), Jakarta: Akademika Pressindo, 1993.

Ismail, Chairuddin, Polisi, Demokrasi VS Anarkhi, Jakarta: Citra, 2000.

Lamintang, P.A.F. Dasar-Dasar Hukum Pidana Indonesia, Bandung: Citra Aditya Bakti, 1997.

Liliweri, Alo, Memahami Peran Komunikasi Massa Dalam Masyarakat, Bandung: Citra Aditya, 1991.

Lettlejohn, W. Stephen, Theories of Human Communication. Wedswort Publishing Company, America. 1999.

Marhaeni, Dwi Pangastuti, Intensitas Peran Komunikasi Interpersonal Dalam Keluarga Untuk Mencegah Kenakalan Remaja, Magister Komunikasi Universitas Jenderal Sudirman, 2011.

Marpaung, Leden. Kejahatan Terhadap Kesusilaan dan Masalah Preverensinya, Jakarta Sinar Grafika, 2004.

Muhammad, Farouk, Pengubahan Perilaku dan Kebudayaan Dalam Rangka Peningkatan Kualitas Pelayanan Polri, Journal of Polisi Indonesia, Year 2, April 2000 - September 2000.

Nasional, Departemen Pendidikan, Kamus Besar Bahasa Indonesia, Jakarta: Gramedia Pustaka Utama, 2008.

Nimmo, Dan, Komunikasi Politik, Komunikator, Pesan dan Media, Penerjemah Tjun Surjaman, Penyunting, Jalaluddin Rakhmat, Bandung: Remaja Karya, 1993.

Pawito, Penelitian Komunikasi Kualitatif, Yogyakarta: PT LKiS Pelangi Aksara, 2007.

Rejeki, Sri Ayu, Hubungan Antara Komunikasi Interpersonal dalam Keluarga dengan Pemahaman Moral pada Remaja, Magister Komunikasi Universitas Gunadarma, 2012.

Rakhmat, Jalaluddin, Phisikologi Komunikasi, Bandung: Remaja Rosdakarya, 2001.

Santoso, Topo, Seksualitas Dan Hukum Pidana, Jakarta : IND-HILL-CO, 1997.

Singarimbun, M. and Effendi, S. (eds.). Metode Penelitian Survei. Jakarta : LP3ES, 1995.

Soesanto, Astrid, S. Komunikasi Sosial di Indonesia. Jakarta: Bina Cipta, 2001.

Sugiyono, Metode Penelitian Administrasi, Bandung: Alfabeta, 2002.

Widjaja, H. A. W, Ilmu Komunikasi, Pengantar Studi, Jakarta: Rineka Cipta, 2000. 